Realism and the Liberal Tradition 

Editors

\title{
Realism and the Liberal Tradition
}

\author{
The International Relations Theory \\ of Whittle Johnston
}


Whittle Johnston

American University

Charlottesville, Virginia, USA

Editors

David Clinton

Baylor University, USA

Waco, Texas, USA

\author{
Stephen Sims \\ Baylor University \\ Waco, Texas, USA
}

ISBN 978-1-137-57763-4

DOI 10.1057/978-1-137-57764-1

ISBN 978-1-137-57764-1 (eBook)

Library of Congress Control Number: 2016944031

(C) The Editor(s) (if applicable) and The Author(s) 2016

This work is subject to copyright. All rights are solely and exclusively licensed by the Publisher, whether the whole or part of the material is concerned, specifically the rights of translation, reprinting, reuse of illustrations, recitation, broadcasting, reproduction on microfilms or in any other physical way, and transmission or information storage and retrieval, electronic adaptation, computer software, or by similar or dissimilar methodology now known or hereafter developed.

The use of general descriptive names, registered names, trademarks, service marks, etc. in this publication does not imply, even in the absence of a specific statement, that such names are exempt from the relevant protective laws and regulations and therefore free for general use. The publisher, the authors and the editors are safe to assume that the advice and information in this book are believed to be true and accurate at the date of publication. Neither the publisher nor the authors or the editors give a warranty, express or implied, with respect to the material contained herein or for any errors or omissions that may have been made.

Cover illustration: (C) Marian Sladek / Getty Images

Printed on acid-free paper

This Palgrave Macmillan imprint is published by Springer Nature

The registered company is Nature America Inc. New York 
Dedicated to the memory of Whittle Johnston 



\section{Preface}

\section{The Missing Man}

Reading the manuscript of Realism and the Liberal Tradition brings back to all of us who had the good fortune of studying with Professor Whittle Johnston the breadth of his learning and the clarity of his insights. Just as in these pages, we heard in the classroom the easy command of the works of all the masters of Western political thought, the effortless employment of illustrations from history ancient and modern, and the evocation of the wisdom or folly of statesmen throughout the ages and throughout the world, all flowing in an unbroken stream of careful argument and exposition. Professor Johnston- "Mr. Johnston" to all who encountered him during the years of his final academic appointment at "Mr. Jefferson's University"-was a superb lecturer, not only because of the care that he had obviously devoted to the preparation of his remarks to us but also because of the commitment to the academic enterprise that he brought to his task. He was, as the colleagues noted who authored their tribute to him following his untimely death, unfailingly courteous and even gentle toward those of any political point of view, and especially toward students, but he nevertheless brought to his teaching a passion for truth, justice, and liberty-all goods that were as essential, in his view, to scholarly life as to political life. ${ }^{1}$ He could in fact become highly animated in the course of his exposition (balling his fists, his face reddening), because he was convinced of the deep importance of the issues he saw at stake. While never employing the lectern as a place to launch partisan political comments, he was always clear in advocating freedom over tyranny, prudence over both 
undue combativeness and dangerous sloth, and clarity of thought over oleaginous phraseology, no matter how superficially appealing the latter might seem.

Johnston saw himself, correctly, as a sympathetic critic —or perhaps more accurately a critical admirer - of both the liberal tradition of political thought and the realist tradition of international thought. As someone who treasured the achievements of individual liberty, constitutional government, and the rule of law, he believed that the modern world owed much to liberalism, even as he feared that in the hands of some of its adherents that tradition could become foolishly confident of the goodness of human nature and blind to the frequent harshness of the political world. As someone who, influenced by those cautionary objections to the excesses of liberalism, was alive to the ever-present element of power in politics, particularly in international relations, and therefore appreciated the realist critique of the errors of liberalism, he nevertheless thought that realists sometimes went too far in dismissing the intellectual accomplishments of liberalism and the beneficent consequences of institutions founded on a conviction of the worth of freedom.

Johnston therefore gives us a carefully nuanced view of both liberalism and realism. In these pages, we find John Locke praised more than Thomas Paine as a political thinker, while liberal practitioners of politics such as Thomas Jefferson and William Gladstone receive distinctly mixed reviews. Sometimes in Johnston's words one has the sense that the liberal tradition has been fortunate in seemingly surmounting the inadequacies of every one of its practical adherents. Likewise, in his treatment of three great twentieth-century international relations thinkers associated with the realist reaction against a shallow liberalism, he made distinctions. His critique of Edward Hallett Carr remains perhaps his best-known work, and he rarely misses an opportunity to remind his reader of the flaw that he insisted lay at the heart of Carr's work-a recognition of the role of power untethered to any system of moral thought that could justify restraints on or criticisms of the use of power. ${ }^{2}$ As Stephen Sims' introductory essay makes clear, Johnston was fully alive to the immense contribution made to our theoretical understanding of international politics by Hans Morgenthau, recognizing Morgenthau as a formative thinker who transformed the intellectual environment within which every subsequent analyst had to work. Yet he contended that Morgenthau's rejection of the excessive confidence of the liberal tradition was often phrased in terms too absolute and uncompromising, so that characteristics that differentiated better regimes from worse faded into a universal contest for power 
in which the individual contestants could not be readily distinguished. His fullest respect seemed given to Reinhold Niebuhr, perhaps because in Niebuhr Johnston recognized that grounding that Johnston feared Carr lacked. In Niebuhr's Augustinian Christianity, Johnston believed that he discerned a clear-eyed recognition of the potency of the will in turning seeming selflessness to self-interested ends, coupled with an insistence on the ultimate worth of each individual human being and the capacity of men and women to recognize and curb their delight in exercising power over others.

All of these evaluations will be familiar to those who encountered Johnston in the seminar room or the lecture hall; one can almost hear him voicing the formulations found in these pages. Yet one immense figure in international relations theory to whom Johnston often referred as a source of wisdom seems to make relatively few appearances in the manuscript, at least at the stage to which Johnston had brought it by the point when his advancing illness made it impossible for him to continue his work. That missing figure is Raymond Aron. My recollection, confirmed by conversations with others who studied with Johnston at roughly the same time, is that he cited Aron (and "Aronian" thinkers such as Stanley Hoffmann) perhaps more than any other single thinker. ${ }^{3}$

This reliance on Aron is not surprising when one recalls that Aron, as with Johnston, saw himself as an inheritor of the liberal tradition, but one with no illusions. For decades, Aron defended liberalism and liberal institutions when that stance was a lonely one to take among French intellectuals; he criticized the USA when he thought it was mistaken or ill intentioned in its foreign policy, but he left no doubt that in the contest between liberal and socialist democracy he stood with the former. Yet he claimed the mantle of "realist" for himself, not least because he recognized that, for all the achievements of "diplomacy," the world of "strategy" in which war remained a real possibility among the participants in international politics always loomed in the background. ${ }^{4}$ Even within this realm of power, however, Aron-and Johnston-insisted that the character of specific regimes led them to behave differently in confronting the demands of security and the lure of predominance. Some tended to behave in ways that were more moderate, respectful, and constructive than others, and these tended to be the liberal democratic countries; such was the insight of liberalism that Aron and Johnston shared. The dual nature of the international conduct of states, combining a necessary determination to acquire and maintain sufficient power to remain secure 
in a dangerous world, on one hand, with a readiness to attempt all the softening effects of diplomacy, international law, and a general attitude of restraint and respect for others, on the other-this complex view of the world was something that Johnston admired in Aron. Yet for neither man could restraint alone keep this complex mechanism going. Johnston, like Aron, suspected that Carr was correct in contending that an imbalance of power in favor of a benevolent regime committed to the preservation of the whole was necessary to its survival. The belief that power was necessary to the continuance of an international order that operated not simply according to power, and that this power would be best exercised by a liberal democratic regime, was summed up in the title of another work of Aron, The Imperial Republic. ${ }^{5}$ It was a view fully endorsed by Johnston.

Drawing, then, upon both the progressive contributions of liberalism and the cautionary contributions of realism, Johnston takes his place alongside Aron as an acute observer and theoretician of international relations. His extended treatment of the intertwining of these two intellectual traditions has long been denied to the world. It is fortunate that it now sees the light of day.

David Clinton 


\section{Acknowledgments}

Our first and greatest debt must naturally go to Whittle Johnston, whose clarity of thought and expression launched a great ship of scholarly study on the decks of which we have spent a bit of time polishing the brass and inspecting the lines. We shall be forever grateful to him for leaving us this admirable work of study, thought, and exposition. Our second debt is to his widow, Martha Johnston, and to the Johnstons' children and their spouses, for allowing us to assist a significant contribution to knowledge, which its author had brought within sight of completion, in those last few steps that would carry it over the finish line. Without the support of the Johnston family to their husband and father, Whittle Johnston, we are certain, would never have exhibited the calm judgment and broad reading that distinguish this important work. Without their generous confidence in us, we would never have had the opportunity to read this manuscript, much less edit it for publication.

David Clinton wishes to thank all of the graduate students who have worked on this manuscript since it was entrusted to the care of the Political Science Department at Baylor University. As a group, they are brilliant, conscientious, and-perhaps of greatest importance to him-tolerant of the foibles of their professor. His most heartfelt appreciation must go to his coeditor, Stephen Sims, who somehow managed to write a brilliant dissertation and earn a PhD while chasing after innumerable citations and determining the author's intent from handwritten notes added at widely varying times. It has been a distinct privilege to work with him, and it will be a great pleasure to watch his ascent to the prominence to which his high character, his rare intelligence, and his constant collegiality entitle him. 
Stephen Sims thanks his mentor and coeditor, Dr. David Clinton, for the opportunity and privilege to work on this manuscript. Dr. Clinton's nobility of soul and gentleness of character remain polestars for a young man setting out on his career. He would also like to thank his family and wife. They made the labor over this manuscript much lighter than it could have been.

\section{Notes}

1. See David Jordan, Jonathan Rice, Robert Turner, Michael Cairo, and Christina Smith, "Stafford Gorman Whittle Johnston," in PS: Political Science \& Politics (March 1997): 89-91.

2. See Whittle Johnston, "E. H. Carr's Theory of International Relations: A Critique," Journal of Politics (November 1967).

3. Hoffmann is in fact extensively quoted throughout the work.

4. Raymond Aron, Peace and War: A Theory of International Relations, trans. Richard Howard and Annette Baker Fox (Garden City, New York: Doubleday and Company, 1966), 21-46.

5. Raymond Aron, The Imperial Republic: The United States and the World 1945-1973, trans. Frank Jellinek (Englewood Cliffs, New Jersey: PrenticeHall, 1974). 


\section{Contents}

Introduction

Part I “The Long Road to Theory" 27

1 Politics and Science 29

2 Politics and Value, Part 1 35

3 Politics and Value, Part 2

4 The Scientist, the Moralist, and the Historian 67

Part II International Relations and History 95

5 The States System 97

6 The Balance of Power 119 
xiv CONTENTS

Part III Liberalism and History

7 The Development of the Liberal Tradition, Part 1

155

8 The Development of the Liberal Tradition, Part 2

9 The Development of the Liberal Tradition, Part 3

Part IV International Relations and Liberalism

10 The Problem of Community

11 The American Alliance System

12 Democratic Theory and International Relations 